\title{
Product Dose
}

National Cancer Institute

\section{Source}

National Cancer Institute. Product Dose. NCI Thesaurus. Code C95344.

A quantity of a product administered, taken, or absorbed at one time. 